〔Med. Entomol. Zool. Vol. 60 No. 2 p. 119-124 2009]

\title{
Mosquito collections from coastal areas of Tokyo Bay receiving migratory birds
}

\author{
Yoshio TsudA ${ }^{1)}$, Emi SASAKI ${ }^{2)}$, Yukita SATO ${ }^{2)}$, Rie KATANO ${ }^{3)}$, \\ Osamu Komagata ${ }^{1)}$, Haruhiko IsAwA ${ }^{1)}$, Shinji KASAI ${ }^{1)}$ \\ and Koichi MURATA ${ }^{2)}$ \\ 1) Department of Medical Entomology, National Institute of Infectious Diseases, \\ Toyama 1-23-1, Shinjuku-ku, Tokyo, 142-8640 Japan \\ ${ }^{2)}$ College of Bioresource Sciences, Nihon University, \\ 1866 Kameino, Fujisawa, 252-0813 Japan \\ 3) Department of Parasitology, Faculty of Veterinary Medicine, Azabu University, \\ Fuchinobe 1-17-71, Sagamihara, Kanagawa, 229-8501 Japan
}

(Received; 8 December 2008; Accepted: 21 January 2009)

\begin{abstract}
Mosquitoes were collected with dry-ice traps from June to October 2006 from coastal areas of Tokyo Bay receiving migratory birds to clarify mosquito fauna and their biting density. The following 6 mosquito species were encountered at Yatsu Higata and Tokyo Port Wild Bird Park; Culex pipiens gr., Aedes albopictus, Cx. inatomii, Cx. tritaeniorhynchus, Cx. bitaeniorhynchus and Lutzia vorax. This study reports the first occurrence of $C x$. inatomii in eastern Japan. Culex pipiens gr. and Ae. albopictus were dominant and are considered to be important potential vectors of West Nile Virus in coastal areas of Tokyo Bay.
\end{abstract}

Key words: mosquito collection, migratory birds, Tokyo Bay, Culex inatomii

\section{INTRODUCTION}

The importance of migratory birds in pathogen dispersion has been demonstrated recently in relation to the spread of Avian influenza and West Nile viruses (Jourdain et al., 2007; Jourdain et al., 2008; Lopez et al., 2008; Yamaguchi and Higuchi, 2008). Many bird species migrate to Japan for breeding, wintering or stopover during long-distance flights (Yamashina Institute for Ornithology, 2002). In mosquito-borne diseases such as West Nile Virus, contact between infected migratory birds and vector mosquitoes is essential for pathogen introduction. Ecological studies on mosquito fauna, their seasonal prevalence and biting behavior in areas receiving migratory birds are important to assess the possible introduction of mosquito-borne diseases by migratory birds.

Mosquitoes were collected from coastal areas of Tokyo Bay receiving migratory birds to clarify mosquito fauna and their biting density in the summer season when many seashore birds, such as sandpipers and plovers, migrate to these areas. Detection of West Nile Virus and avian malarial parasites in the collected mosquitoes were conducted and the results will be published elsewhere.

\section{Materials And Methods}

Study site: Two coastal areas of Tokyo Bay, Yatsu Higata Nature Observation Center and Tokyo Port Wild Bird Park, were selected for the present study (Fig. 1). Both areas are included in the East AsianAustralasian Shorebird Reserve Network and many migratory birds from eastern Russia, Korea, China, Southeast Asia and 

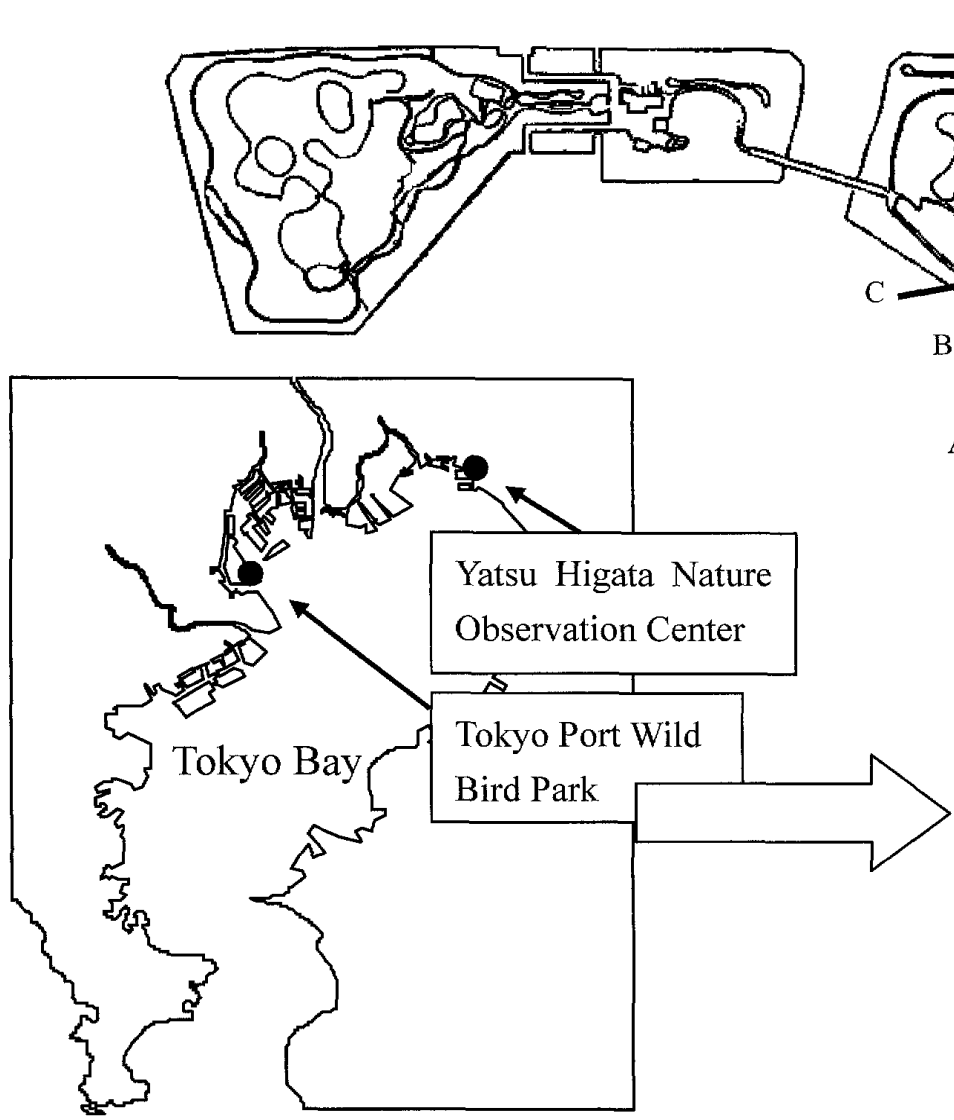

Fresh water pond

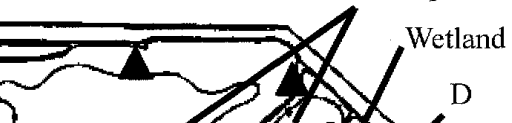

B

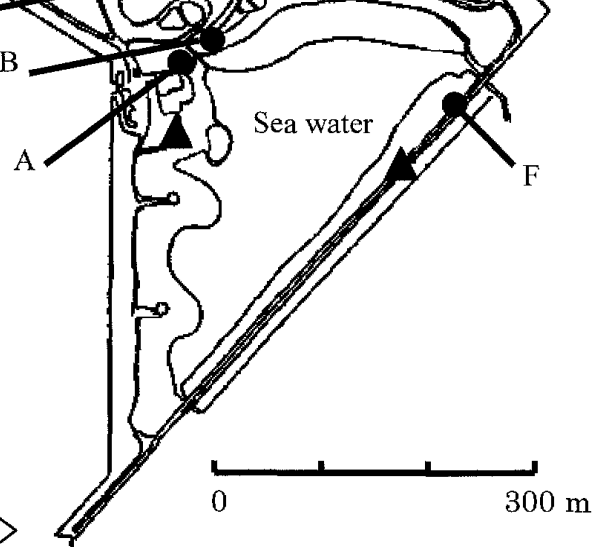

Fig. 1. Map showing the location of the two study sites and a detail map of Tokyo Port Wild Bird Park with the trap collection sites. Closed circles and triangles indicate the permanent and optional trap sites, respectively. Hatched area indicates the wetland where Culex inatomii larvae were collected.

Australia were observed and recorded (Wild Bird Society of Japan, 2006; Yamashina Institute for Ornithology, 2002). Yatsu Higata and Tokyo Port Wild Bird Park are 40 ha and 24.2 ha, respectively. Yatsu-Higata is surrounded by residential areas where mosquito larval habitats are limited, whereas a variety of larval habitats are present in Tokyo Port Wild Bird Park and it seems a suitable place for the ecological study of mosquitoes inhabiting coastal areas of Tokyo Bay.

Mosquito collections: Seashore birds, such as sandpipers and plovers, migrate to the present study sites in summer, so mosquitoes were collected once in August 2006 at Yatsu Higata and 4 times from June to October 2006 at Tokyo Port Wild Bird Park. Mosquitoes were collected using battery-operated CDC-like suction traps enhanced with $1 \mathrm{~kg}$ of dry ice. The dry ice was wrapped in a piece of paper, covered with a plastic bag and kept in a cooler bag. In most cases a small piece of dry ice remained when mosquitoes were collected the next morning. Ten to 20 of the dry-ice traps were fixed to trees $1.2-2$ $\mathrm{m}$ from the ground and operated for 24 hrs. Mosquito samples were collected the next morning and carried to the National Institute of Infectious Diseases for species identification. Mosquitoes were identified following Tanaka et al. (1979) and Tanaka (2003). Culex pipiens pallens Coquillett and $C x$. pipiens form molestus Forskål were expected to be in the study sites, but, they were not identified because of difficulty in morphological identification and treated as $C x$. pipiens gr. in this study.

The collection sites at Tokyo Port Wild Bird Park are shown in Fig. 1. In total, 11 sites were selected for mosquito collection and 6 ( $\mathrm{A}$ to $\mathrm{F}$ in Fig. 1) were used permanently during the study. Additionally, 3 collection sites were selected from the 
Table 1. Results of mosquito collections by dry ice-traps at 2 locations in coastal areas of Tokyo Bay, Japan in 2006.

\begin{tabular}{|c|c|c|c|c|c|c|c|c|}
\hline & \multirow[b]{2}{*}{ Species } & \multirow{2}{*}{ 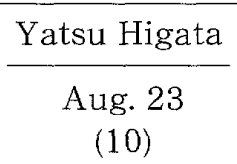 } & \multicolumn{5}{|c|}{ Tokyo Port Wild Bird Park } & \multirow{2}{*}{$\begin{array}{c}\text { Total } \\
(80)\end{array}$} \\
\hline & & & $\begin{array}{c}\text { June } 20 \\
(10)\end{array}$ & $\begin{array}{c}\text { Aug. } 1 \\
(20)\end{array}$ & $\begin{array}{c}\text { Sep. } 6 \\
(20)\end{array}$ & $\begin{array}{l}\text { Oct. } 18 \\
(20)\end{array}$ & $\begin{array}{l}\text { Sub total } \\
(70)\end{array}$ & \\
\hline \multirow{5}{*}{ Female } & Culex pipiens gr. & 344 & 49 & 559 & 261 & 35 & 904 & 1,248 \\
\hline & Aedes albopictus & 7 & 28 & 136 & 192 & 19 & 375 & 382 \\
\hline & $C x$. inatomii & 2 & 79 & 16 & 0 & 0 & 95 & 97 \\
\hline & Cx. tritaeniorhynchus & 8 & 0 & 74 & 13 & 3 & 90 & 98 \\
\hline & Cx. bitaeniorhynchus & 0 & 0 & 23 & 1 & 0 & 24 & 24 \\
\hline \multirow{6}{*}{ Male } & Lutzia vorax & 0 & 0 & 1 & 0 & 0 & 1 & 1 \\
\hline & Female total & 361 & 156 & 809 & 467 & 57 & 1,489 & 1,850 \\
\hline & Ae. albopictus & 0 & 1 & 15 & 2 & 0 & 18 & 18 \\
\hline & Cx. tritaeniorhynchus & 0 & 0 & 0 & 0 & 0 & 0 & 0 \\
\hline & Male total & 0 & 1 & 15 & 2 & 0 & 18 & 18 \\
\hline & Total & 361 & 157 & 824 & 469 & 57 & 1,507 & 1,868 \\
\hline
\end{tabular}

Numbers in parentheses show the number of dry-ice traps used for mosquito collection.

remaining 5 sites (shown by triangles in Fig. 1). In June 2006, one trap was placed at each of the 9 collection sites, except for site $\mathrm{D}$ where 2 traps were placed. In August, September and October 2006, the numbers of traps per collection site were doubled so 20 traps were used for mosquito collections.

Larval collections were made twice at Tokyo Port Wild Bird Park. The edge of a fresh water pond, sea water pool and wetland (hatched area in Fig. 1) were examined by dipping on 28 June 2006. Because no mosquito larvae were collected from the fresh water pond and sea water pool, small ground pools appearing in the wetland were examined again on 4 July 2006.

\section{RESULTS}

The results of mosquito collections at the 2 study areas are shown in Table 1. The following 6 mosquito species were encountered at Yatsu Higata and Tokyo Port Wild Bird Park; Culex pipiens gr. Aedes albopictus (Skuse), CX. inatomii Kamimura \& Wada, Cx. tritaeniorhynchus Giles, Cx. bitaeniorhynchus Giles and Lutzia vorax Edwards. This study reports the first record of the occurrence of $C x$. inatomii in eastern Japan. Culex pipiens gr. was domi- nant at both study sites and comprised $95 \%$ and $67 \%$ of all females collected at Yatsu Higata and Tokyo Port Wild Bird Park, respectively. Although the total number of $C x$. inatomii collected at Tokyo Port Wild Bird Park was small, 97 (5\% of all females), the density was highest in June and markedly decreased thereafter, mainly because the larval habitats dried up in midsummer. In larval collections at Tokyo Port Wild Bird Park conducted on 28 June and 4 July 2006, Cx. inatomii larvae were collected from small ground pools in the wetlands (hatched area in Fig. 1) together with larvae of $C x$. tritaeniorhynchus and Anopheles sinensis.

Variations in female density (/trap/day) observed at 6 permanent collection sites at Tokyo Port Wild Bird Park are shown in Table 2 for 4 dominant species. Uneven distribution of biting females among the 6 collection sites was observed for all species. Biting females of $C x$. pipiens gr. were abundant in August and 79\% were collected from 3 sites, A, C and E suggesting a wider search area of this species than other species. Aedes albopictus was abundant in August and September and $85 \%$ of females were collected from 2 collection sites, $\mathrm{E}$ and $\mathrm{F}$, located near bushy areas. Culex inatomii was abundant in June and $82 \%$ of females were collected at site C, 
Table 2. Variation in female density (/trap/day) observed at 6 collection sites at Tokyo Port Wild Bird Park from June to October 2006.

\begin{tabular}{|c|c|c|c|c|c|c|c|c|c|c|}
\hline \multirow[b]{2}{*}{ Site } & \multicolumn{5}{|c|}{ Ae. albopictus } & \multicolumn{5}{|c|}{$C x$ pipiens group } \\
\hline & June 20 & Aug. 1 & Sep. 6 & Oct. 18 & Total & June 20 & Aug. 1 & Sep. 6 & Oct. 18 & Total \\
\hline $\mathrm{A}$ & 0 & 0 & 10 & 1 & 11 & 10 & 63 & 41 & 4 & 118 \\
\hline B & 0 & 1 & 0 & 0 & 1 & 1 & 33 & 19 & 1 & 54 \\
\hline $\mathrm{C}$ & 0 & 0 & 4 & 0 & 4 & 16 & 87 & 99 & 5 & 207 \\
\hline $\mathrm{D}$ & 1 & 2 & 14 & 2 & 19 & 3 & 17 & 6 & 2 & 28 \\
\hline $\mathrm{E}$ & 8 & 90 & 28 & 1 & 127 & 11 & 181 & 15 & 0 & 207 \\
\hline $\mathrm{F}$ & 0 & 4 & 62 & 9 & 75 & 0 & 46 & 16 & 1 & 63 \\
\hline \multirow[t]{2}{*}{ Total } & 9 & 97 & 118 & 13 & 237 & 41 & 427 & 196 & 13 & 677 \\
\hline & \multicolumn{5}{|c|}{ Cx. inatomii } & \multicolumn{5}{|c|}{ Cx. tritaeniorhynchus } \\
\hline Site & June 20 & Aug. 1 & Sep. 6 & Oct. 18 & Total & June 20 & Aug. 1 & Sep. 6 & Oct. 18 & Total \\
\hline A & 0 & 1 & 0 & 0 & 1 & 0 & 0 & 0 & 0 & 0 \\
\hline B & 5 & 0 & 0 & 0 & 5 & 0 & 3 & 0 & 0 & 3 \\
\hline $\mathrm{C}$ & 63 & 8 & 0 & 0 & 71 & 0 & 60 & 6 & 3 & 69 \\
\hline D & 5 & 3 & 0 & 0 & 8 & 0 & 2 & 2 & 0 & 4 \\
\hline $\mathrm{E}$ & 0 & 0 & 0 & 0 & 0 & 0 & 3 & 0 & 0 & 3 \\
\hline $\mathrm{F}$ & 1 & 1 & 0 & 0 & 2 & 0 & 4 & 0 & 0 & 4 \\
\hline Total & 74 & 13 & 0 & 0 & 87 & 0 & 72 & 8 & 3 & 83 \\
\hline
\end{tabular}

next to their larval habitats. At site $C, C x$. tritaeniorhynchus was abundant in August and $83 \%$ of females were collected there.

\section{DISCUSSION}

Ecological studies on mosquito fauna, their seasonal prevalence and biting behavior in areas receiving migratory birds are important to assess the possible introduction of mosquito-borne diseases by migratory birds. Because migratory bird fauna in a certain area changes seasonally, the seasonal prevalence, biting time and biting place of mosquitoes are crucial factors determining bird-vector contact. The results of our mosquito collections indicated the importance of $C x$. pipiens gr. as a potential vector of West Nile Virus because of a high density and wide search area. Aedes albopictus is also an important potential vector of West Nile virus in the daytime, because this species is susceptible to the virus (Turell et al., 2005) and is a very active daytime biter (Hawley, 1988). Both species are common in urban areas as well as rural areas of Japan and are considered to be potential vectors of West Nile Virus in a large part of the country (Tsuda et al., 2006a, b; Kobayashi et al., 2008). However, as shown in the present study, $A$ e. albopictus shows a clumped distribution of biting females (Takagi et al., $1995 \mathrm{a}, \mathrm{b}, \mathrm{c})$ and their biting density is high near bushes. Therefore, contact between Ae. albopictus and wild birds may be limited to bird species resting during the daytime beside or inside the bushes.

The occurrence of $C x$. inatomii in eastern Japan was first reported in this study. Reports on the distribution of this species in Japan has been limited to Okayama (Kamimura and Wada, 1974), Kansai International Airport (Mizuta et al., 1999) and coastal areas of Kobe and Osaka (Mizuta unpublished). However, the occurrence of this species has been reported on the coast of Ulsan, Korea (Ree, 1998) and in our recent mosquito survey of Niigata and Kushiro (Tsuda unpublished). Therefore, $C x$. inatomii appears to have a wide geographic distribution, including Japan and Korea. Because $C x$. modestus, a species related to $C x$. inatomii, is susceptible to West 
Nile Virus (Balenghien et al., 2007) and suggested as a major vector of West Nile Virus in Volgograd, Russia (Fyodorova et al., 2006) and southern France (Balenghien et al., 2006), Cx. inatomii may have an important role in the transmission of West Nile Virus in Japan if the virus is introduced. More ecological studies on the distribution and biting behavior of $C x$. inatomii are necessary to evaluate the importance of this species as a mosquito vector.

We assumed a positive correlation between trap capture and biting density of mosquitoes but biting density on birds may differ greatly among bird species depending on the host preference of the mosquito species and availability of blood source animals. Blood-fed mosquito collections and blood-meal identifications are important and necessary in future studies to accurately quantify mosquito-bird contacts in the present study sites.

\section{ACKNOWLEDGEMENTS}

We thank Yatsu-Higata Nature Observation Center and Tokyo Port Wild Bird Park for helping with mosquito collections. This study was partly supported by a Grant-in-Aid for Scientific Research of Emerging and Reemerging Infectious Diseases from the Ministry of Health, Labor and Welfare of the Japanese Government (H18-Shinko-009), the Global Environment Research Fund of the Ministry of the Environment, Japan (F-062), and the Academic Frontier Project from the Ministry of Education, Culture, Sports, Science and Technology, Japan and Nihon University Research Grants.

\section{REFERENCES}

Balenghien, T., Fouque, F., Sabatier, P. and Bicout, D. J. 2006. Horse-, bird-, and human-seeking behavior and seasonal abundance of mosquitoes in a West Nile Virus focus of southern France. J. Med. Entomol., 43: 936-946.

Balenghien, T., Vazeille, M., Reiter, P., Schaffner, F., Zeller, H. and Bicout, D. J. 2007. Evidence of labora- tory vector competence of Culex modestus for West Nile Virus. J. Am. Mosq. Control Assoc., 23: 233-236. Fyodorova, M. V., Savage, H. M., Lopatina, J. V., Bulgakova, T. A., Ivanitsky, A. V., Platonova, O. V. and Platonova, A. E. 2006. Evaluation of potential West Nile Virus vectors in Volgograd region, Russia, 2003 (Diptera: Culicidae): species composition, bloodmeal host utilization, and virus infection rates of mosquitoes. J. Med. Entomol., 43: 552-563.

Hawley, W. A. 1988. The biology of Aedes albopictus. J. Am. Mosq. Control Assoc. Suppl., 1: 1-39.

Jourdain, E., Gauthier-Clerc, M., Bicout, D. and Sabatier, P. 2007. Bird migration routes and risk for pathogen dispersion into western Mediterranean wetland. Emerg. Inf. Dis., 13: 365-372.

Jourdain E., Zeller, H. G., Sabatier, P., Murri, S., Kayser, Y., Greenland, T., Lafaye, M. and GauthierClerc, M. 2008. Prevalence of West Nile neutralizing antibodies in wild birds from the Camargue area, southern France. J. Wildl. Dis., 44: 766-771.

Kamimura, K. and Wada, Y. 1974. A new subspecies of Culex (Barraudius) modestus from Japan (Diptera: Culicidae). Jpn. J. Sanit. Zool., 25: 13-20.

Kobayashi, M., Kasai, S., Sawabe, K. and Tsuda, Y. 2008. Distribution and ecology of potential vector mosquitoes of West Nile Fever in Japan. Global Env. Res., 12: 27-33.

López, G., Jiménez-Clavero, M. A., Tejedor, C. G., Soriguer, R. and Figuerola, J. 2008. Prevalence of West Nile Virus neutralizing antibodies in Spain is related to the behavior of migratory birds. Vector Borne Zoonotic Dis., 8: 615-621.

Mizuta, H., Matsumoto, A., Goto, K. and Kotake, K. 1999. Investigation of mosquito breeding at Kansai International Airport, with special reference to Culex inatomii Kamimura and Wada. Med. Entomol. Zool., 50: 161-164 (In Japanese with English abstract).

Ree, H. L. 1998. Occurrence of Culex (Barraudius) inatomii Kamimura and Wada (Diptera: Culicidae) in a large marsh adjacent to the coast of U1san, Korea. J. Am. Mosq. Control Assoc., 14: 344-345.

Takagi, M., Tsuda, Y., Suzuki, A. and Wada, Y. 1995a. Movement of individually marked Aedes albopictus females in Nagasaki, Japan. Trop. Med, 37: 79-85.

Takagi, M., Tsuda, Y. and Wada, Y. 1995b. Movement and oviposition of released Aedes albopictus (Diptera:Culicidae) in Nagasaki, Japan. Jpn. J. Sanit. Zool., 46: 131-138. 
Takagi, M., Tsuda, Y. and Wada, Y. 1995c. Temporal and spatial distribution of released Aedes albopictus(Diptera: Culicidae) in Nagasaki, Japan. Jpn. J. Sanit. Zool., 46: 223-228.

Tanaka, K. 2003. Studies on the pupal mosquitoes of Japan (9). Genus Lutzia, with establishment of two new subgenera, Metalutzia and Insulalutzia (Diptera: Culicidae). Jpn. J. Syst. Entomol., 9: 159169.

Tanaka, K., Mizusawa, K. and Saugstad, E. S. 1979. A revision of the adult and larval mosquitoes of Japan (including the Ryukyu archipelago and the Ogasawara islands) and Korea (Diptera: Culicidae). Cont. Am. Entomol. Inst., 16: 1-987.

Tsuda, Y., Higa, Y., Kasai, S., Isawa H., Hoshino, K., Hayashi, T., Komagata, O., Sawabe, K., Sasaki, T., Tomita, T., Nihei, N., Kurahashi, H. and Kobayashi, M. 2006a. Results of mosquito collection at four areas near Narita International Airport, Japan, in 2003 and 2004. Med. Entomol. Zool., 57: 211-218 (In Japanese with English abstract).

Tsuda, Y., Higa, Y., Kurahashi, H., Hayashi, T.,
Hoshino, K., Komagata, O., Isawa, H, Kasai, S., Sasaki, T., Tomita, T., Sawabe, K., Nihei, N. and Kobayashi, M. 2006b. Dry-ice trap collection of mosquitoes at urban areas surrounding Tokyo, Japan in 2003 and 2004. Med. Entomol. Zool., 57: 75-82 (In Japanese with English abstract).

Turell, M. J., Dohm, D. J., Sardekusm M. R., O'guinn, M. L., Andreadis, T. G. and Blow, J. A. 2005. An update on the potential of North American mosquitoes (Diptera: Culicidae) to transmit West Nile virus. J. Med. Entomol., 42: 57-62.

Wild Bird Society of Japan. 2006. Annual Report of Tokyo Port Wild Bird Park 2005.95pp., Wild Bird Society of Japan, Tokyo (In Japanese).

Yamaguchi, N. and Higuchi, H. 2008. Migration of birds in east Asia with reference to the spread of avian influenza. Global Env. Res., 12: 41-54.

Yamashina Institute for Ornithology. 2002. Atlas of Japanese Migratory Birds from 1961 to 1995.161 pp., Yamashina Institute for Ornithology, Abiko (In Japanese). 